\title{
The Importance of Innovation during the Design Process of Rain Rubber Boot
}

\author{
Y. Yu, Y.T. Wang, H.Y. Ru \\ Donghua University \\ China
}

\begin{abstract}
In this study, the relationship of air permeability properties to rain rubber boot were investigated. There are all kinds of styles, colour and pattern rain rubber boots now in the market. But most of the costumers rather a wet shoe than wearing rain rubber boots. The mainly reason is the air permeability of the rubber material. The foot may feel very uncomfortable and airtight; this situation is generally caused by allergy or inflammation of sweat glands arising from airtight skin and obstruction of pores. Now therefore, in this situation, it is very necessary to find a innovative way to design a new rain boot with waterproof, breathable function. This study raises different viewpoint and shows a creative ideas through analyst the design process of rain boot, research the rain boots now in the market.
\end{abstract}

Keywords-rain rubber boots; air permeability; innovative

\section{BACKGROUND OF RAIN RUBBER BOOTS}

The rain rubber boots is quite necessary equipment in rainy days. This kind of boots is waterproof and is most often made from rubber or polyvinyl chloride (PVC) a Halogenation polymer [1]. They are usually worn when walking on wet or muddy ground, or to protect the wearer from heavy showers and puddles. They are generally just below knee-high although shorter boots are available. The rain boot is shown in Figure 1. There are all kinds of styles, color and pattern rain rubber boots now in the market. But most of the costumers rather a wet shoe than wearing rain rubber boots. Why people don't like wearing rain rubber boots in rainy days? How to solve the problems to make people love rain rubber? It's entirely feasible to develop the market if we can find the reasons and solve them with innovative designs.
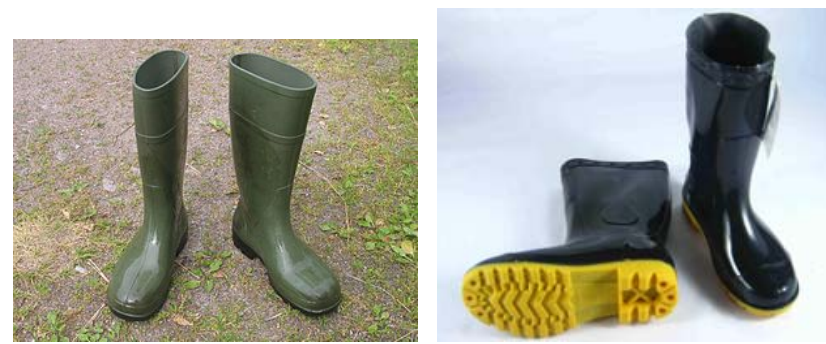

FIGURE I. MODERN RAIN RUBBER BOOTS

\section{AnAlysis of the Design Process of RAin BoOts}

Like Steve Jobs says, "You know, we don't grow most of the food we eat. We wear clothes other people make. We speak a language that other people developed. We use a mathematics that other people evolved... I mean, we're constantly taking things. It's a wonderful, ecstatic feeling to create something that puts it back in the pool of human experience and knowledge.”If there is no creativity, there is no plenty of new products, new technologies, new processes, new materials, human beings could not enjoy such a colorful modern life [2] .To meet the consumers' demands, the study try to analysis the design process of rain boots in four parts: material, color, shape and functions.

\section{A. The Material}

The mainly material is rubber; include natural rubber, synthetic rubber and synthetic resin [3]. It will be a long-term trend that these three categories is the mainly material of rain boots. Natural rubber has been gathered from the sap of plants for centuries. Natural rubber offers good elasticity, while synthetic materials tend to offer better resistance to environmental factors such as oils, temperature, chemicals or ultraviolet light and suchlike. Synthetic rubber did not have the strength for radials; only natural rubber could provide the required sturdiness. Synthetic resins are materials with a property of interest that is similar to natural plant resins: they are viscous liquids that are capable of hardening permanently. Synthetic resin provides a new way of making shoes. They are not in conflict but complementary each with its own sphere of competence [4]. In the design process, it is delivering amazing results through adding special materials in to the rubber. Such as specific fluorescent particles, which color, is vivid and vigorous.

\section{B. The Colour and Ornament}

The results to date suggest that color is the first impression of the products that gives a person; the second is modeling appearance and then the texture. The color can always give a person rich imagination. Take the book 2014/2015 Spring/Summer SHANGHAI STYLE FASHION TREND>. For example, sketch out the trend of color and ornament in footwear design process.

\begin{tabular}{|l|l|}
\hline \multicolumn{2}{|c|}{ Classic| Star dreams over the sea } \\
\hline \multirow{3}{*}{ Profile } & $\begin{array}{l}\text { Neon lights in shanghai night exude } \\
\text { classic feelings .it arouse people`s } \\
\text { interest and nostalgia of old } \\
\text { shanghai. }\end{array}$ \\
\hline \multirow{2}{*}{ color } & \\
\hline
\end{tabular}

(a) 


\begin{tabular}{|l|l|}
\hline \multicolumn{2}{|c|}{ Natural| Living the dream } \\
\hline \multirow{3}{*}{ Profile } & $\begin{array}{l}\text { Shoes are made with breathable } \\
\text { materials and simple design, mainly } \\
\text { focuses on reusing. }\end{array}$ \\
\hline \multirow{3}{*}{ Color } & \\
\cline { 2 - 2 } & $\begin{array}{l}\text { The earth-toned colors like Green, } \\
\text { Blue Grey }\end{array}$ \\
\hline
\end{tabular}

(b)

\begin{tabular}{|l|l|}
\hline \multicolumn{2}{|c|}{ Modern |Enjoy colorful dreams } \\
\hline \multirow{3}{*}{ Profile } & $\begin{array}{l}\text { Contrasting hue, changeable Lego } \\
\text { style color blocks and attractive } \\
\text { shoestring add sophistication to the } \\
\text { sole. }\end{array}$ \\
\hline \multirow{5}{*}{ Color } & \\
\cline { 2 - 2 } & $\begin{array}{l}\text { candy colors like Jaffa orange, } \\
\text { Candy pink }\end{array}$ \\
\hline
\end{tabular}

(c)

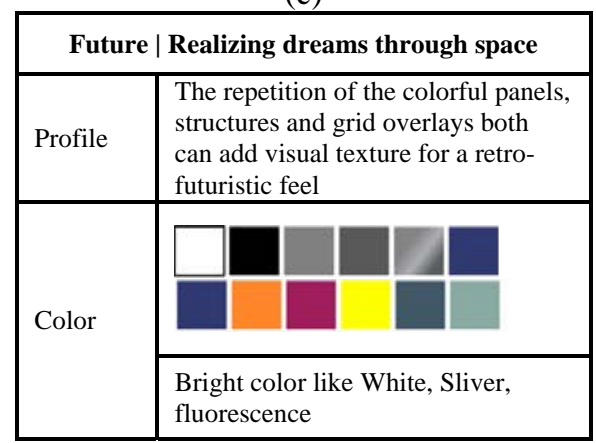

(d)

FIGURE II. THE PROFILE OF 2014/2015 SPRING/SUMMER SHANGHAI STYLE FASHION TREND

\section{The Modeling Appearance and Functionality}

1) The modeling appearance: The modeling appearance shows the external direct-viewing impression. When design the modeling appearance of the rain boots, can use the innovative ideas in both the local design and overall appearance of the footwear.

In the local design, add some texture, the rivets, hollowedout like Figure 3.

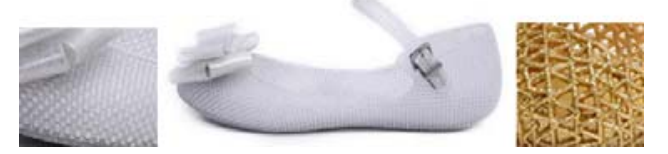

FIGURE III. MELISSA HOOP DOT HOLLOW OUT FLATTIE

In the overall appearance design, using geometrical shape, organic forms like lFigure3.

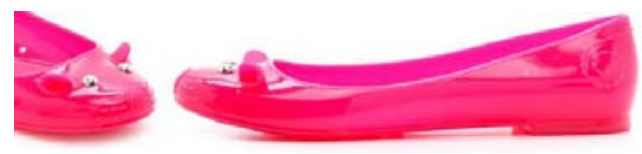

FIGURE IV. MOUSE FACE FLATTIE

2) Combine the modeling appearance with functionality: The basic function of rain rubber boots is waterproof and nonskid [5]. There are various styles of them, such as high-leg rain boots, middle-leg rain boots, shoe with short toe top line and so on. They can also divide into high-heel, middle-heel and flat heel. Different style has different functions and advantages, taking shoe with short toe top line for example, its waterproof is not stronger enough than high-leg boot, but it is portable and easy to wear. Therefore, designer should use innovative mind to design different modeling appearance to meet the customers' need.

Some designers give several new ideas to solve the problems of heavy and airtight of the modeling appearance like the boot in Figure5. This boot is designed for the people who ride a bicycle. It is easy to take off, wash and keep.

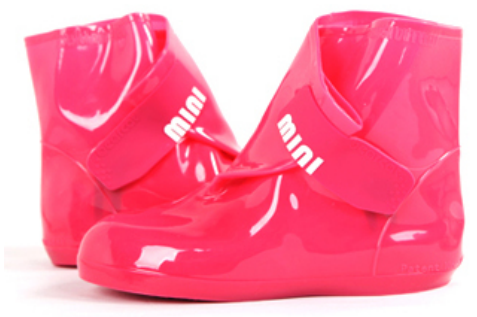

FIGURE V. RAINCOAT OF BOOTS

\section{DESIGN Practice OF THE RAIN Rubber BoOtS}

The air permeability is the biggest disadvantage of rain rubber boots. It is always in a state of relatively high temperature and humidity inside of the shoes, excessive sweat with the foot of the mixture of bacteria, fungi, sebum, and shoes together will produce unpleasant tastes. Focus on this air permeability problem; the authors try to give some solutions.

This rain boots have several exhaust pipes on the top of the surface, the pipes can let the air in and waterproof at the same time. In the modeling appearance design, the inspiration comes from digital technology and Purifying water pipe to show vigor of life. 

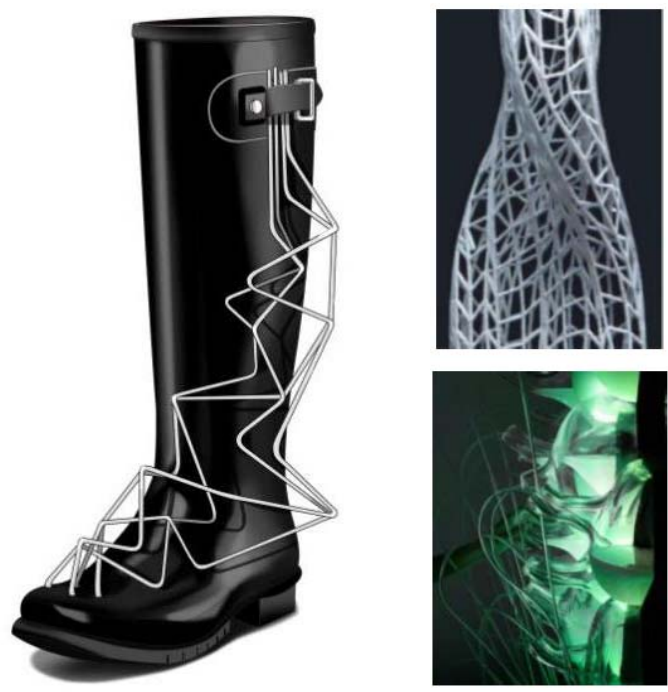

FIGURE VI.RENDERING

FIGURE VII. INSPIRATION
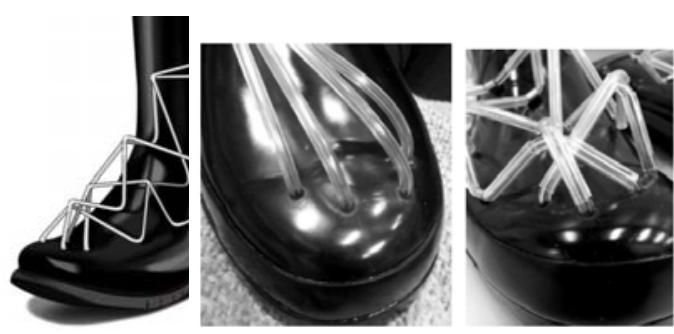

FIGURE VIII. DETAILS

FIGURE IX.MAKING MODELS

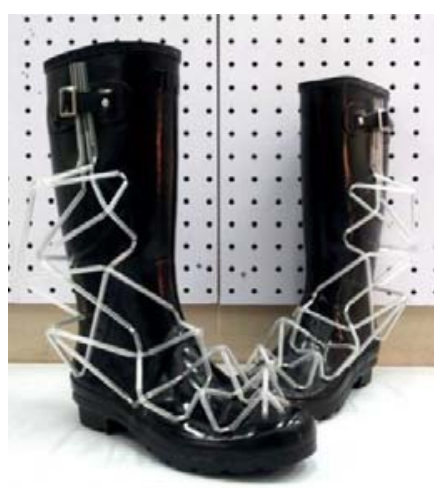

FIGURE X. FINAL PRODUCTS

\section{CONCLUSION}

In this study, the relationship of air permeability properties to rain rubber boot were investigated. There are all kinds of styles, colour and pattern rain rubber boots now in the market. But most of the costumers rather a wet shoe than wearing rain rubber boots. The mainly reason is the air permeability of the rubber material. The foot may feel very uncomfortable and airtight; this situation is generally caused by allergy or inflammation of sweat glands arising from airtight skin and obstruction of pores. Now therefore, in this situation, it is very necessary to find an innovative way to design a new rain boot with waterproof, breathable function. This study raises different viewpoint and shows a creative ideas through analyst the design process of rain boot, research the rain boots now in the market. Because the time and strength limits, there are still some parts that need to improve.

\section{ACKNOWLEDGEMENTS}

The programs of shanghai universities technology platformDonoghue university shanghai style fashion design and value creation center.

\section{REFERENCES}

[1] Borah, Jyotishmoy, Wang, Chuansheng. Morphological and flame retardant behaviors of rubber-modified asphalt. Key Engineering Materials, v 501, p 532-537, 2012, Progress in Polymer Processing

[2] Mohamed, M.K., Samy, A.M.; Ali, W.Y. Friction coefficient of rubber shoe soles sliding against ceramic flooring, KGK Kautschuk Gummi Kunststoffe, v 64, n 4, p 44-49, April 2011

[3] Mohamed, M.K., Samy, A.M. Friction coefficient of rubber shoes sliding against ceramic flooring. KGK Kautschuk Gummi Kunststoffe, v 65, n 1-2, p 52-57, January-February 2012

[4] X.H.Liu. Creative design methods using. [M]. Chemical industry publish, 2006.7:41.

[5] X.G.Zhao.the current situation of the mainly materials of rubber shoes [J]. China Rubber.2007 (15) 